\title{
Selenium Decreases the Cadmium Content in Brown Rice: Foliar Se Application to Plants Grown in Cd-contaminated Soil
}

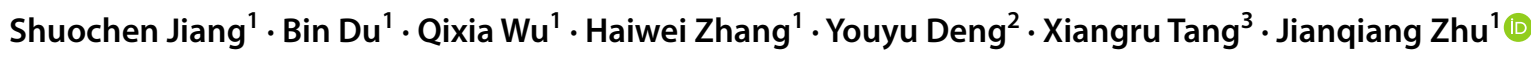

Received: 15 July 2021 / Accepted: 23 November 2021 / Published online: 1 January 2022

(c) The Author(s) 2021

\begin{abstract}
Cadmium (Cd) contamination in agricultural soils has become a serious issue owing to its high toxicity threat to human health through the food chain. The purpose of this paper is to explore the availability of foliar selenium (Se) application in reducing Cd enrichment in brown rice. A field experiment from 2017 to 2019 was conducted to investigate the effects of foliar Se application on the physiology and yields of three rice cultivars and their accumulation of Cd in low-Cd and high-Cd soils. The grain protein contents and yields of rice plants grown in the high-Cd soil were lower than those of plants cultivated in the low-Cd soil by $27.85 \%$ and $6.82 \%$, whereas the malondialdehyde (MDA) and Cd contents were higher by $66.06 \%$ and $91.47 \%$, respectively. Se application reduced $\mathrm{Cd}$ translocation from the stems and leaves to the spikes, decreasing the $\mathrm{Cd}$ content in brown rice by $40.36 \%$. Additionally, Se enhanced the antioxidative activity, glutathione and protein contents, and rice yield (7.58\%) and decreased the MDA and proline contents. However, these Se effects weakened under the high-Cd soil. Foliar Se application can alleviate $\mathrm{Cd}$-induced physiological stress in brown rice while improving its yield and reducing its $\mathrm{Cd}$ content.
\end{abstract}

Keywords Antioxidants $\cdot$ Cadmium accumulation $\cdot$ Food safety $\cdot$ Heavy metal $\cdot$ Sodium selenite $\cdot$ Yield

\section{Introduction}

Rice (Oryza sativa L.) is a staple food which is consumed by approximately $50 \%$ of the worldwide population (Sharma et al. 2017). Soil contamination with heavy metals badly affects the growth and yield of crops, causing severe threats to grain security and human health through the food chain (Huang et al. 2017a, b

). Of the top 20 toxic heavy metals, $\mathrm{Cd}$ is ranked 7 th owing to its high solubility and toxicity and is considered one of the most hazardous metals with high mobility in

Shuochen Jiang Bin Du and Qixia Wu contributed equally to this work.

Jianqiang Zhu

200572@yangtzeu.edu.cn

1 College of Agriculture, Yangtze University, Jingzhou 434025, China

2 Agriculture and Rural Affairs Bureau of Taojiang County, Yiyang 413400, China

3 School of Agriculture, South China Agricultural University, Guangdong 510642, China plants ( $\mathrm{Li}$ et al. 2017). In rice plants, Cd causes leaf chlorosis and leads to the inhibition of biomass production and thereby yield loss (Treesubsuntorn et al. 2018). The toxic effects of Cd vary among different rice cultivars, where Cdtolerant varieties tend to have a higher proline content and more antioxidative activity under $\mathrm{Cd}$ stress than $\mathrm{Cd}$-sensitive cultivars (Wan et al. 2018).

The essential mineral Se is a heavy metal antagonist with antioxidative properties (Huang et al. 2017a, b); it has been reported of Se to interact with Cd intracellularly in plants (Guo et al. 2021). It was shown to have a particularly protective effect on crops by reducing the toxicity of Cd (Qingqing et al. 2019). Uraguchi et al. revealed that the root-to-shoot translocation of $\mathrm{Cd}$ via the xylem was the major and common physiological process determining the $\mathrm{Cd}$ accumulation level in grains. Their study inadvertently provided a research framework for using Se to reduce $\mathrm{Cd}$ accumulation in grains; that is, by applying the mineral directly to soil (Uraguchi et al. 2009). Numerous studies have shown that Se application in soil could significantly restrict the soil-to-grain translocation of $\mathrm{Cd}$ and relieve the oxidative stress caused by the toxic metal (Huang et al. 2017a, b; Qingqing et al. 2019). However, when a Se-based fertiliser is applied to soil, more 
than $80 \%$ of the selenites are adsorbed onto ferric soil minerals and form $\mathrm{Fe}-\mathrm{Mn}$ oxide-bound $\mathrm{Se}$ and organic-bound $\mathrm{Se}$, which cannot be absorbed and utilised by rice, resulting in $80-95 \%$ of the selenates being leached out by irrigation or rainfall (Huang et al. 2017a, b; Qingqing et al. 2019). Furthermore, the antagonistic effects of sulphur on Se in soil can significantly limit the latter's absorption by rice plants (Liu et al. 2015). Additionally, long periods of flooding and anaerobic conditions can accelerate selenate leaching and selenite fixation (Deng et al. 2017). A foliar spray of Se is generally more bioavailable and environmentally friendly than its applied directly in soil (Deng et al. 2017). Currently, there are few reports on the effects of foliar Se spraying on rice cultivars planted in Cd-contaminated soil. Gao et al. (2018) reported that foliar Se spraying reduced the $\mathrm{Cd}$ transport coefficient from the roots to the leaves, stems, and grains in a pot environment. However, there are sizable differences between fields and pots in the growth of rice plants.

We hypothesised that foliar Se application would relieve oxidative stress and reduce $\mathrm{Cd}$ accumulation in brown rice and increase the grain yield. In order to verify the effectiveness of foliar Se spraying in reducing $\mathrm{Cd}$ accumulation in grains for future application to Cd-contaminated soils, a field experiment was of foliar Se application conducted for three rice cultivars that were planted in Cd-contaminated soils.

\section{Materials and Methods}

\subsection{Experimental Site and Description}

The experiments were conducted from 2017 to 2019 in Taojiang County, Hunan Province, China $\left(111^{\circ} 36^{\prime} \mathrm{N}-112^{\circ} 19^{\prime} \mathrm{N}\right.$, $\left.28^{\circ} 13^{\prime} \mathrm{E}-28^{\circ} 41^{\prime} \mathrm{E}\right)$. The region has a humid subtropical continental climate with an annual average temperature of $16.2-17.5^{\circ} \mathrm{C}$ and annual rainfall of $1466-1634 \mathrm{~mm}$. Before the field trials, 20 fields $\left(1000 \mathrm{~m}^{2}\right)$ were selected extensively and randomly in the county. Five soil samples $(0-20 \mathrm{~cm})$ were collected from each field and mixed as a representative sample of that field. The soils were tested for their total nitrogen, alkaline hydrolysed nitrogen, available phosphorus, available potassium, organic matter, total $\mathrm{Cd}$, and total Se contents and pH. Finally, two experimental fields were selected that had similar soil indicators except for the $\mathrm{Cd}$ content in soils. The soil properties are listed in Table 1 . The soil type was clay loam in both fields. The planting mode for the two fields was double-season rice + milk vetch before 2017, that is, crops planted at the same paddy fields were early-rice, late-rice, and green manure in order, and the planting mode was changed to one-season rice (mid-rice) + milk vetch from 2017 to 2019. Rice cultivars for our experiment were "Huanghuazhan" (HHZ), "Cliangyou 386" (CLY), and "Yuzhenxiang" (YZX), supplied by the Yiyang Agricultural Bureau. Under the conventional management mode, the yield of HHZ (conventional indica), CLY386 (hybrid indica), and YZX (conventional indica) are $7500-8000 \mathrm{~kg} \bullet \mathrm{ha}^{-1}, 8000-8500 \mathrm{~kg} \bullet \mathrm{ha}^{-1}$, $6000^{-} 6500 \mathrm{~kg} \bullet \mathrm{ha}^{-1}$, respectively, and the growth period is 136 days, 139 days, and 115 days, respectively.

\subsection{Experimental Treatments}

Experiments were arranged in a split-split plot design, with the soil Cd content as the main plot and the Se treatments and rice cultivars as subplots, in three replications. The experimental plot is rectangular in shape, 4-m wide and 6-m long. Two fields with different $\mathrm{Cd}$ content in soils were chosen which are a low-Cd field (Anlingping Village, $0.339 \mathrm{mg} \cdot \mathrm{kg}^{-1} \mathrm{Cd}$ ) and a high-Cd field (Xiaopotou Village, $0.950 \mathrm{mg} \cdot \mathrm{kg}^{-1} \mathrm{Cd}$ ). According to the China Soil Environment Quality Standard, GB15618-2018), Cd content in soils lower than the grade I reference value $\left(0.3 \mathrm{mg} \cdot \mathrm{kg}^{-1}\right)$ generally barely affect the cultivation of rice, and the content exceed the grade III reference value $\left(1.0 \mathrm{mg} \cdot \mathrm{kg}^{-1}\right)$ is unsuitable for planting crops and vegetables (Zhang et al. 2015). In the study, the Cd content in the low-Cd cropland is slightly higher than the grade I reference value and that in the high$\mathrm{Cd}$ farmland is slightly lower than the grade III reference value. Thus, these soils can better reflect the application and promotional value of foliar Se spraying. Two treatments were applied: foliar spraying with $110 \mathrm{~g} \cdot \mathrm{ha}^{-1}$ sodium selenite (50 g.ha ${ }^{-1} \mathrm{Se}$, based on that used by Deng et al. (2017)) or foliar spraying with clean water $\left(0 \mathrm{~g} \cdot \mathrm{ha}^{-1} \mathrm{Se}\right.$, as the control plot). Each of the three rice varieties was grown in the two fields with low or high soil Cd contents and sprayed with Se or water, giving a total of 12 treatment groups.

During 2017-2019, pre-germinated seeds of the three rice varieties were sown into seedbeds on May 1st of each year.

Table 1 Basic components of the experimental topsoil $(0-20 \mathrm{~cm})$

\begin{tabular}{|c|c|c|c|c|c|c|c|c|}
\hline Location & $\begin{array}{l}\text { Total N } \\
\mathrm{g} \mathrm{kg}^{-1}\end{array}$ & $\begin{array}{l}\text { Alkaline } \\
\text { hydrolysed } \mathrm{N} \\
\mathrm{mg} \mathrm{kg}^{-1}\end{array}$ & $\begin{array}{l}\text { Available P } \\
\mathrm{mg} \mathrm{kg}^{-1}\end{array}$ & $\begin{array}{l}\text { Available } \mathrm{K} \\
\mathrm{mg} \mathrm{kg}^{-1}\end{array}$ & $\begin{array}{l}\text { Organic matter } \\
\mathrm{mo} \mathrm{ko}^{-1}\end{array}$ & $\begin{array}{l}\text { Total cadmium } \\
\mathrm{mo} \mathrm{kg}^{-1}\end{array}$ & $\begin{array}{l}\text { Total selenium } \\
\mathrm{mo} \mathrm{kg}^{-1}\end{array}$ & $\overline{\mathrm{pH}}$ \\
\hline Low-Cd area & 2.1 & 140.4 & 12.6 & 157.8 & 24.8 & 0.339 & 0.243 & 5.0 \\
\hline High-Cd area & 1.9 & 128.9 & 16.8 & 136.4 & 23.4 & 0.95 & 0.219 & 5.9 \\
\hline
\end{tabular}


On June 1st of each year, the seedlings were transplanted into the two paddy fields with a plant spacing of $20 \mathrm{~cm}$ and row spacing of $25 \mathrm{~cm}$, with two seedlings per planting pit. Each plot was applied fertiliser with the available nutrient of $\mathrm{N} 150, \mathrm{P}_{2} \mathrm{O}_{5} 59$, and $\mathrm{K}_{2} \mathrm{O} 120 \mathrm{~kg} \cdot \mathrm{ha}^{-1}$ in the form of $\mathrm{CO}\left(\mathrm{NH}_{2}\right)_{2},\left(\mathrm{NH}_{4}\right)_{2} \mathrm{HPO}_{4}$, and $\mathrm{KCl}$, respectively. Specifically, $60 \%$ of $\mathrm{N}$ was applied as basal fertiliser and the remaining $40 \%$ as a tillering fertiliser, whereas $100 \%$ of the $\mathrm{P}_{2} \mathrm{O}_{5}$ and $\mathrm{K}_{2} \mathrm{O}$ components were applied as base fertilizers. Se was applied at the booting and heading periods (i.e., when $10 \%$ and $50 \%$, respectively, of the spikes protrude from the sheath of the flag leaf), with half-strength concentrations $\left(25 \mathrm{~g} \cdot \mathrm{ha}^{-1} \mathrm{Se}\right)$ sprayed each time. Weeds, pests, and diseases were intensively controlled to avoid loss of grain yield.

\subsection{Sampling and Data Collection}

At the flowering and maturity stages, the aboveground parts of three plants from each replicate were collected, rinsed with tap water, and then rinsed again with distilled water. Thereafter, the plant samples were divided into stems, leaves, spikes, and brown rice (at maturity). These components were then dried in an oven at $75^{\circ} \mathrm{C}$, ground, and passed through a 100-mesh sieve, following which their $\mathrm{Cd}$ contents were estimated. At the flowering stage, fresh flag leaves from three plants of each replicate were collected and stored at $-80^{\circ} \mathrm{C}$ for their biochemical analysis.

For the determination of the Cd content, $0.2 \mathrm{~g}$ of the plant sample was mixed with nitric acid (66-68\%, v/v) and perchloric acid $(70-72 \%, \mathrm{v} / \mathrm{v})$ in a mixture ratio of $4: 1(\mathrm{v} / \mathrm{v})$, then cover and soak for $12 \mathrm{~h}$. The mixture was digested in a heating plate at $200{ }^{\circ} \mathrm{C}$, then diluted to $25 \mathrm{ml}$ with $16 \%$ hydrochloric acid. The $\mathrm{Cd}$ content was measured using an AA6300C atomic absorption spectrophotometer (Shimadzu, Japan) (GB 5009.15-2014).

For the evaluation of the superoxide dismutase (SOD), peroxidase (POD), catalase (CAT), and ascorbate peroxidase (APX) activities and malondialdehyde (MDA) and protein contents, the fresh flag leaf samples were ground in liquid nitrogen to form a homogenate. Then, $9 \mathrm{ml}$ of $50 \mathrm{mM}$ sodium phosphate buffer ( $\mathrm{pH} 7.8$ ) was added to the homogenate, and the mixture was processed by centrifuge at $8000 \mathrm{rpm}, 12,000$ times of gravity for $15 \mathrm{~min}$ at $4{ }^{\circ} \mathrm{C}$. The enzyme activities and MDA and protein contents in the supernatant were then determined according to the methods described by Huang et al. (2020). One unit of SOD activity was defined as the amount of enzyme that resulted in a $50 \%$ inhibition of the initial rate of nitroblue tetrazolium reduction at $560 \mathrm{~nm}$. The mixture for determining POD activity consisted of $1 \mathrm{ml}$ of sodium phosphate buffer ( $\mathrm{pH} 7.8$ ), $0.95 \mathrm{ml}$ of $0.2 \%$ guaiacol, $1 \mathrm{ml}$ of $0.3 \% \mathrm{H}_{2} \mathrm{O}_{2}$, and $0.05 \mathrm{ml}$ of the supernatant sample, and the absorbance was measured at $470 \mathrm{~nm}$ for $90 \mathrm{~s}$ at 30 -s intervals. One unit of POD activity was defined as the amount of enzyme that caused the decomposition of $1 \mathrm{mg}$ of a substrate at $470 \mathrm{~nm}$. The mixture for determining CAT activity consisted of $1.95 \mathrm{ml}$ of distilled water, $1 \mathrm{ml}$ of $0.3 \% \mathrm{H}_{2} \mathrm{O}_{2}$, and $0.05 \mathrm{ml}$ of the supernatant sample, and the absorbance was measured at $470 \mathrm{~nm}$ for $90 \mathrm{~s}$ at 30-s intervals. One unit of CAT activity was defined as the decomposition of $1 \mathrm{M} \mathrm{H}_{2} \mathrm{O}_{2}$ at $\mathrm{A}_{240}$ within $1 \mathrm{~min}$ in $1 \mathrm{~g}$ of fresh leaf sample. The mixture for determining APX activity consisted of $50 \mathrm{mM}$ phosphate buffer ( $\mathrm{pH} 7.0), 0.1 \mathrm{mM}$ EDTA, $0.5 \mathrm{mM}$ ascorbic acid, $0.1 \mathrm{mM} \mathrm{H}_{2} \mathrm{O}_{2}$, and $0.1 \mathrm{ml}$ of the supernatant sample, and the absorbance was measured at $290 \mathrm{~nm}$ for $90 \mathrm{~s}$. One unit of APX activity was defined as the amount catalyzing the oxidation of $1 \mu \mathrm{mol}$ ascorbic acid per minute. To determine the MDA content, $1.5 \mathrm{ml}$ of the supernatant sample was mixed with $0.5 \mathrm{ml}$ of a thiobarbituric acid solution prepared in 5\% trichloroacetic acid and boiled at $100{ }^{\circ} \mathrm{C}$ for $30 \mathrm{~min}$. Thereafter, the sample was cooled and then centrifuged at $3000 \mathrm{rpm}$ for $15 \mathrm{~min}$. Finally, the absorbance was measured at 450,532, and $600 \mathrm{~nm}$, and the MDA content was calculated using the following formula: $\mathrm{MDA}$ content $=6.45\left(\mathrm{OD}_{532}-\mathrm{OD}_{600}\right)-0.599\left(\mathrm{OD}_{450}\right)$. To determine the protein content, $0.1 \mathrm{ml}$ of the supernatant sample was mixed with $0.9 \mathrm{ml}$ of ultrapure water and $5 \mathrm{ml}$ of Coomassie Brilliant Blue G-250 Reagent on a vortexer, and the absorbance of the mixture was then measured at $595 \mathrm{~nm}$. A standard curve was used to calculate the protein content. The proline content in $0.3 \mathrm{~g}$ of fresh flag leaves was measured according to the method described by Du et al. (2019). In brief, the leaf sample was first homogenised in $80 \%$ ethanol. Then, $2 \mathrm{ml}$ of proline and $4 \mathrm{ml}$ of $1.25 \%$ ninhydrin in glacial acetic acid were added to the homogenate and the mixture was boiled at $100{ }^{\circ} \mathrm{C}$ for $30 \mathrm{~min}$, and the absorbance was then measured at $508 \mathrm{~nm}$ and a standard curve was used to calculate the proline content. The glutathione (GSH) content was determined using the method described by $\mathrm{Li}$ et al. (2015). In brief, $0.2 \mathrm{~g}$ of fresh flag leaves were ground in $3 \mathrm{ml}$ of $5 \%$ trichloroacetic acid solution, following which the homogenate was centrifuged at $8000 \mathrm{rpm}$ for $20 \mathrm{~min}$ at $4{ }^{\circ} \mathrm{C}$. Then, $0.1 \mathrm{ml}$ of the supernatant was mixed with $4.4 \mathrm{ml}$ of $0.1 \mathrm{M}$ phosphate-buffered saline ( $\mathrm{pH} 7.0$ ) and $0.5 \mathrm{ml}$ of $0.4 \%$ (w/v) 5,5'-dithiobis(2-nitrobenzoic acid), and the mixture was incubated at $30^{\circ} \mathrm{C}$ for $5 \mathrm{~min}$ in the dark. Thereafter, the absorbance was measured at $412 \mathrm{~nm}$, and a standard curve was used to calculate the GSH content.

\subsection{Statistical Analyses}

All experimental data are expressed as the mean \pm standard error of three replicates. The normal distribution and homogeneity of variance of the data were tested using the Shapiro-Wilk test and Levene's test in SPSS 21.0, respectively. The value of SOD, POD, and CAT activities, spikelet filling, and rice yield satisfied normal distribution and 
homogeneity of variance and were therefore analyzed using one-way analysis of variance and the Student's $t$-test to determine the effects of the rice variety, $\mathrm{Cd}$, and Se, respectively. The value of APX activity, MDA, protein, proline, and GSH contents, panicle density, spikelets per panicle, 1000-grain weight, and Cd content did not satisfy normal distribution and homogeneity of variance and were therefore analyzed using nonparametric tests to determine the effects of the rice variety, $\mathrm{Cd}$, and $\mathrm{Se}$, respectively. Spearman's correlation coefficients ( $r$ values) were determined to evaluate the relationships between the various plant characteristics. The histograms were drawn using Origin, and the heat map was drawn using TBtools.

\section{Results}

\subsection{Cadmium Contents in Rice}

The Cd contents in rice were ranked as 2019>2017> 2018 (Table 2, 3, 4). The Cd content in the spikes at the mature stage of CLY386 was significantly lower than that of YZX and HHZ. Compared with rice plants cultivated in the low$\mathrm{Cd}$ soil, $\mathrm{Cd}$ contents in the stems, leaves, and spikes of the plants grown in the high-Cd soil, respectively, increased by $153.51 \%, 141.00 \%$, and $46.69 \%$ at the flowering stage of rice, by $246.72 \%, 213.69 \%$, and $87.93 \%$ at the mature stage, while the Cd content in brown rice increased by $91.47 \%$. The effect of Se on the Cd content in different organs of rice plants at the flowering stage was unstable in 3 years; it may be that the weather when Se was applied affected the absorption efficiency of Se by rice. Generally, Se treatment significantly affected $\mathrm{Cd}$ accumulation in rice plants at the mature stage, increasing the heavy metal content in the stems and leaves by $32.47 \%$ and $44.30 \%$, respectively, and decreasing it in the spikes and brown rice by $29.30 \%$ and $40.36 \%$, respectively. Se application reduced the $\mathrm{Cd}$ accumulation in brown rice by $47.94 \%$ in low-Cd soils and by $36.37 \%$ in high-Cd soils, confirming that the ability of Se application to reduce the $\mathrm{Cd}$ transport from stems and leaves to spikes is weakened with the increment of soil Cd content.

\subsection{Rice Physiological Index}

There were significant differences in POD and APX activities between different years. POD activity was the highest in 2018, and APX activity in 2018 and 2019 was higher than in 2017 (Fig. 1). The CAT activity of CLY386 and YZX were significantly higher than that of $\mathrm{HHZ}$, and the MDA content of YZX was significantly higher than that of CLY386 and HHZ (Fig. 2). Compared with low-Cd soil, the MDA increased by $66.06 \%$ and protein reduced by $27.85 \%$ for rice plants cultivated in the high-Cd soil from 2017 to 2019. On average, Se application enhanced SOD, POD, CAT, and APX activities by $25.03 \%, 24.88 \%$, $56.39 \%$, and $46.38 \%$, respectively, decreased MDA $(25.23 \%)$ and proline content $(34.08 \%)$, and increased GSH (97.21\%) and protein (69.35\%) content from 2017 to 2019. In high-Cd soils, the role of Se application in improving plant metabolism was weakened (including the

Table 2 Effects of soil Cd contamination and foliar Se treatment on the Cd content $\left(\mathrm{mg} \cdot \mathrm{kg}^{-1}\right)$ in the stems, leaves, and spikes at the flowering stage, mature stage, and brown rice of three rice cultivars grown in 2017

\begin{tabular}{|c|c|c|c|c|c|c|c|c|c|}
\hline \multirow[t]{2}{*}{ Cultivars $^{\mathrm{a}}$} & \multirow[t]{2}{*}{$\mathrm{Cd}$} & \multirow[t]{2}{*}{$\mathrm{Se}^{\mathrm{b}}$} & \multicolumn{3}{|l|}{ Flowering stage } & \multicolumn{3}{|l|}{ Mature stage } & \multirow[t]{2}{*}{ Brown rice } \\
\hline & & & Stem & Leaf & Spike & Stem & Leaf & Spike & \\
\hline \multirow[t]{4}{*}{ V1 } & \multirow[t]{2}{*}{ Low-Cd } & $\mathrm{Se} 0$ & $1.178 \pm 0.040 \mathrm{c}$ & $0.439 \pm 0.011 f$ & $0.130 \pm 0.005 f$ & $0.547 \pm 0.008 \mathrm{gh}$ & $0.249 \pm 0.005 \mathrm{i}$ & $0.706 \pm 0.013 \mathrm{~h}$ & $0.530 \pm 0.017 \mathrm{~h}$ \\
\hline & & $\mathrm{Se} 1$ & $1.205 \pm 0.017 \mathrm{c}$ & $0.465 \pm 0.037 f$ & $0.138 \pm 0.002 \mathrm{ef}$ & $0.754 \pm 0.031 \mathrm{f}$ & $0.330 \pm 0.011 \mathrm{gh}$ & $0.588 \pm 0.021 \mathrm{i}$ & $0.326 \pm 0.010 \mathrm{k}$ \\
\hline & \multirow[t]{2}{*}{ High-Cd } & $\mathrm{Se} 0$ & $3.417 \pm 0.258 \mathrm{a}$ & $1.464 \pm 0.063 b$ & $0.217 \pm 0.014 \mathrm{bc}$ & $2.176 \pm 0.166 \mathrm{c}$ & $0.756 \pm 0.047 \mathrm{~d}$ & $1.876 \pm 0.060 \mathrm{~b}$ & $1.363 \pm 0.026 b$ \\
\hline & & Se1 & $3.476 \pm 0.114 \mathrm{a}$ & $1.564 \pm 0.074 \mathrm{a}$ & $0.268 \pm 0.018 \mathrm{a}$ & $2.907 \pm 0.051 \mathrm{a}$ & $1.272 \pm 0.033 b$ & $1.339 \pm 0.067 \mathrm{~d}$ & $0.915 \pm 0.016 \mathrm{~d}$ \\
\hline \multirow[t]{4}{*}{ V2 } & \multirow[t]{2}{*}{ Low-Cd } & $\mathrm{Se} 0$ & $1.360 \pm 0.039 \mathrm{c}$ & $0.643 \pm 0.034 \mathrm{e}$ & $0.106 \pm 0.003 \mathrm{~g}$ & $0.613 \pm 0.015 \mathrm{fg}$ & $0.410 \pm 0.019 \mathrm{f}$ & $0.776 \pm 0.016 \mathrm{~g}$ & $0.745 \pm 0.013 f$ \\
\hline & & Se1 & $1.197 \pm 0.014 \mathrm{c}$ & $0.621 \pm 0.019 \mathrm{e}$ & $0.133 \pm 0.004 \mathrm{ef}$ & $0.747 \pm 0.066 f$ & $0.486 \pm 0.017 \mathrm{e}$ & $0.550 \pm 0.010 \mathrm{i}$ & $0.367 \pm 0.024 \mathrm{j}$ \\
\hline & \multirow[t]{2}{*}{ High-Cd } & $\mathrm{Se} 0$ & $2.942 \pm 0.089 b$ & $1.138 \pm 0.065 \mathrm{~d}$ & $0.184 \pm 0.002 \mathrm{~d}$ & $1.931 \pm 0.108 \mathrm{~d}$ & $0.947 \pm 0.021 \mathrm{c}$ & $1.264 \pm 0.026 \mathrm{e}$ & $1.018 \pm 0.024 \mathrm{c}$ \\
\hline & & Se1 & $2.950 \pm 0.098 \mathrm{~b}$ & $1.106 \pm 0.086 \mathrm{~d}$ & $0.181 \pm 0.008 \mathrm{~d}$ & $2.341 \pm 0.163 b$ & $1.255 \pm 0.067 \mathrm{~b}$ & $0.800 \pm 0.019 \mathrm{~g}$ & $0.641 \pm 0.010 \mathrm{~g}$ \\
\hline \multirow[t]{4}{*}{ V3 } & \multirow[t]{2}{*}{ Low-Cd } & $\mathrm{Se} 0$ & $1.262 \pm 0.097 \mathrm{c}$ & $0.498 \pm 0.046 \mathrm{f}$ & $0.113 \pm 0.002 \mathrm{~g}$ & $0.426 \pm 0.011 \mathrm{~h}$ & $0.288 \pm 0.006 \mathrm{hi}$ & $0.920 \pm 0.026 f$ & $0.797 \pm 0.023 \mathrm{e}$ \\
\hline & & Se1 & $1.302 \pm 0.047 \mathrm{c}$ & $0.442 \pm 0.005 \mathrm{f}$ & $0.146 \pm 0.010 \mathrm{e}$ & $0.580 \pm 0.010 \mathrm{~g}$ & $0.378 \pm 0.025 \mathrm{fg}$ & $0.791 \pm 0.017 \mathrm{~g}$ & $0.431 \pm 0.007 \mathrm{i}$ \\
\hline & \multirow[t]{2}{*}{ High-Cd } & $\mathrm{Se} 0$ & $2.941 \pm 0.131 b$ & $1.378 \pm 0.018 b c$ & $0.206 \pm 0.011 \mathrm{c}$ & $1.337 \pm 0.016 \mathrm{e}$ & $0.950 \pm 0.093 \mathrm{c}$ & $2.148 \pm 0.044 \mathrm{a}$ & $1.729 \pm 0.050 \mathrm{a}$ \\
\hline & & $\mathrm{Se} 1$ & $3.118 \pm 0.113 b$ & $1.336 \pm 0.073 \mathrm{c}$ & $0.222 \pm 0.005 b$ & $2.072 \pm 0.050 \mathrm{c}$ & $1.418 \pm 0.041 \mathrm{a}$ & $1.520 \pm 0.030 \mathrm{c}$ & $1.035 \pm 0.015 \mathrm{c}$ \\
\hline Cultivars & & & $* *$ & $* *$ & $* *$ & $* *$ & $* *$ & $* *$ & $* *$ \\
\hline Cd treatment & & & $* *$ & $* *$ & $* *$ & $* *$ & $* *$ & $* *$ & $* *$ \\
\hline Se treatment & & & $\mathrm{ns}$ & ns & ** & $* *$ & ** & $* *$ & $* *$ \\
\hline
\end{tabular}

Values shown are the mean $\pm \mathrm{SE}(n=3) .{ }^{\mathrm{a}} \mathrm{V} 1, \mathrm{~V} 2$, and V3 represent rice variety "Huanghuazhan," rice variety "Cliangyou 386," and rice variety "Yuzhenxiang," respectively. ${ }^{b} \mathrm{SeO}$, no Se application; $\mathrm{Se}$ 1, Se application; $n s$, no significant effects; *significant effect at the $P<0.05$ level; **significant effect at the $P<0.01$ level. The same letter among are not significantly different according to Duncan's $(0.05)$ 
Table 3 Effects of soil Cd contamination and foliar Se treatment on the Cd content $\left(\mathrm{mg} \cdot \mathrm{kg}^{-1}\right)$ in the stems, leaves, and spikes at the flowering stage, mature stage, and brown rice of three rice cultivars grown in 2018

\begin{tabular}{|c|c|c|c|c|c|c|c|c|c|}
\hline \multirow[t]{2}{*}{ Cultivars $^{\mathrm{a}}$} & \multirow[t]{2}{*}{$\mathrm{Cd}$} & \multirow[t]{2}{*}{$\mathrm{Se}^{\mathrm{b}}$} & \multicolumn{3}{|l|}{ Flowering stage } & \multicolumn{3}{|l|}{ Mature stage } & \multirow[t]{2}{*}{ Brown rice } \\
\hline & & & Stem & Leaf & Spike & Stem & Leaf & Spike & \\
\hline \multirow[t]{4}{*}{ V1 } & \multirow[t]{2}{*}{ Low-Cd } & $\mathrm{Se} 0$ & $1.020 \pm 0.029 \mathrm{~g}$ & $0.480 \pm 0.035 \mathrm{ef}$ & $0.107 \pm 0.002 \mathrm{e}$ & $0.412 \pm 0.012 \mathrm{~h}$ & $0.200 \pm 0.005 \mathrm{i}$ & $0.833 \pm 0.022 \mathrm{~g}$ & $0.717 \pm 0.032 \mathrm{f}$ \\
\hline & & Se1 & $1.206 \pm 0.025 \mathrm{ef}$ & $0.458 \pm 0.018 \mathrm{ef}$ & $0.124 \pm 0.007 \mathrm{~d}$ & $0.643 \pm 0.010 \mathrm{f}$ & $0.316 \pm 0.015 \mathrm{~h}$ & $0.705 \pm 0.019 \mathrm{i}$ & $0.382 \pm 0.016 \mathrm{~h}$ \\
\hline & \multirow[t]{2}{*}{ High-Cd } & $\mathrm{Se} 0$ & $3.041 \pm 0.093 b$ & $1.439 \pm 0.067 \mathrm{a}$ & $0.235 \pm 0.006 \mathrm{a}$ & $1.928 \pm 0.050 \mathrm{c}$ & $0.650 \pm 0.020 \mathrm{f}$ & $1.966 \pm 0.024 \mathrm{a}$ & $1.391 \pm 0.039 \mathrm{a}$ \\
\hline & & Se1 & $3.386 \pm 0.068 \mathrm{a}$ & $1.338 \pm 0.082 \mathrm{~b}$ & $0.233 \pm 0.002 \mathrm{ab}$ & $2.547 \pm 0.093 a$ & $1.364 \pm 0.011 b$ & $1.335 \pm 0.066 \mathrm{c}$ & $1.070 \pm 0.008 \mathrm{~b}$ \\
\hline \multirow[t]{4}{*}{$\mathrm{V} 2$} & \multirow[t]{2}{*}{ Low-Cd } & $\mathrm{Se} 0$ & $1.287 \pm 0.088 \mathrm{e}$ & $0.605 \pm 0.009 \mathrm{~d}$ & $0.165 \pm 0.006 c$ & $0.526 \pm 0.012 \mathrm{~g}$ & $0.389 \pm 0.026 \mathrm{~g}$ & $0.943 \pm 0.053 \mathrm{ef}$ & $0.871 \pm 0.015 \mathrm{~d}$ \\
\hline & & Se1 & $1.151 \pm 0.014 \mathrm{f}$ & $0.545 \pm 0.022 \mathrm{de}$ & $0.128 \pm 0.006 \mathrm{~d}$ & $0.673 \pm 0.004 f$ & $0.383 \pm 0.005 \mathrm{~g}$ & $0.722 \pm 0.028 \mathrm{hi}$ & $0.401 \pm 0.010 \mathrm{~h}$ \\
\hline & \multirow[t]{2}{*}{ High-Cd } & $\mathrm{Se} 0$ & $2.808 \pm 0.116 \mathrm{~d}$ & $1.318 \pm 0.013 b$ & $0.232 \pm 0.019 \mathrm{ab}$ & $1.380 \pm 0.060 \mathrm{e}$ & $0.917 \pm 0.019 \mathrm{~d}$ & $1.570 \pm 0.020 \mathrm{~b}$ & $1.345 \pm 0.047 \mathrm{a}$ \\
\hline & & Se1 & $2.904 \pm 0.068 \mathrm{~cd}$ & $1.225 \pm 0.076 \mathrm{c}$ & $0.225 \pm 0.014 \mathrm{ab}$ & $2.228 \pm 0.094 \mathrm{~b}$ & $1.130 \pm 0.070 \mathrm{c}$ & $0.920 \pm 0.046 \mathrm{f}$ & $0.705 \pm 0.018 \mathrm{f}$ \\
\hline \multirow[t]{4}{*}{ V3 } & \multirow[t]{2}{*}{ Low-Cd } & $\mathrm{Se} 0$ & $1.177 \pm 0.034 \mathrm{ef}$ & $0.548 \pm 0.015 \mathrm{de}$ & $0.095 \pm 0.004 \mathrm{e}$ & $0.383 \pm 0.024 \mathrm{~h}$ & $0.303 \pm 0.006 \mathrm{~h}$ & $1.011 \pm 0.030 \mathrm{~d}$ & $0.942 \pm 0.032 \mathrm{c}$ \\
\hline & & Se1 & $1.113 \pm 0.036 \mathrm{fg}$ & $0.422 \pm 0.009 \mathrm{f}$ & $0.124 \pm 0.004 d$ & $0.559 \pm 0.018 \mathrm{~g}$ & $0.335 \pm 0.019 \mathrm{~h}$ & $0.773 \pm 0.037 \mathrm{gh}$ & $0.503 \pm 0.021 \mathrm{~g}$ \\
\hline & \multirow[t]{2}{*}{ High-Cd } & $\mathrm{Se} 0$ & $2.776 \pm 0.083 \mathrm{~d}$ & $1.330 \pm 0.085 b$ & $0.218 \pm 0.006 b$ & $1.808 \pm 0.048 \mathrm{~d}$ & $0.846 \pm 0.015 \mathrm{e}$ & $1.593 \pm 0.055 b$ & $1.332 \pm 0.073 \mathrm{a}$ \\
\hline & & Se1 & $2.948 \pm 0.121 b c$ & $1.362 \pm 0.078 \mathrm{ab}$ & $0.233 \pm 0.007 \mathrm{ab}$ & $2.488 \pm 0.032 \mathrm{a}$ & $1.514 \pm 0.040 \mathrm{a}$ & $1.00 \pm 0.017 \mathrm{de}$ & $0.785 \pm 0.031 \mathrm{e}$ \\
\hline Cultivars & & & $* *$ & $\mathrm{~ns}$ & $* *$ & $* *$ & $* *$ & $* *$ & $* *$ \\
\hline $\mathrm{Cd}$ treatment & & & $* *$ & $* *$ & $* *$ & $* *$ & $* *$ & $* *$ & $* *$ \\
\hline Se treatment & & & $* *$ & $* *$ & $\mathrm{~ns}$ & $* *$ & $* *$ & $* *$ & $* *$ \\
\hline
\end{tabular}

Values shown are the mean $\pm \mathrm{SE}(n=3) .{ }^{\mathrm{a}} \mathrm{V} 1, \mathrm{~V} 2$, and V3 represent rice variety "Huanghuazhan," rice variety "Cliangyou 386," and rice variety "Yuzhenxiang," respectively. ${ }^{b} \mathrm{SeO}$, no Se application; Se1, Se application; $n s$, no significant effects; *significant effect at the $P<0.05$ level; **significant effect at the $P<0.01$ level. The same letter among are not significantly different according to Duncan's $(0.05)$

Table 4 Effects of soil Cd contamination and foliar Se treatment on the Cd content $\left(\mathrm{mg} \cdot \mathrm{kg}^{-1}\right)$ in the stems, leaves, and spikes at the flowering stage, mature stage, and brown rice of three rice cultivars grown in 2019

\begin{tabular}{|c|c|c|c|c|c|c|c|c|c|}
\hline \multirow[t]{2}{*}{ Cultivars $^{\mathrm{a}}$} & \multirow[t]{2}{*}{$\mathrm{Cd}$} & \multirow[t]{2}{*}{$\mathrm{Se}^{\mathrm{b}}$} & \multicolumn{3}{|l|}{ Flowering stage } & \multicolumn{3}{|l|}{ Mature stage } & \multirow[t]{2}{*}{ Brown rice } \\
\hline & & & Stem & Leaf & Spike & Stem & Leaf & Spike & \\
\hline \multirow[t]{4}{*}{ V1 } & \multirow[t]{2}{*}{ Low-Cd } & $\mathrm{Se} 0$ & $1.242 \pm 0.021 \mathrm{fg}$ & $0.572 \pm 0.038 \mathrm{e}$ & $0.133 \pm 0.008 \mathrm{~cd}$ & $0.501 \pm 0.017 \mathrm{~h}$ & $0.205 \pm 0.004 \mathrm{k}$ & $0.779 \pm 0.025 \mathrm{i}$ & $0.576 \pm 0.015 \mathrm{~g}$ \\
\hline & & Se1 & $1.231 \pm 0.035 \mathrm{~g}$ & $0.561 \pm 0.013 \mathrm{e}$ & $0.122 \pm 0.004 \mathrm{de}$ & $0.651 \pm 0.054 \mathrm{~g}$ & $0.235 \pm 0.004 \mathrm{k}$ & $0.629 \pm 0.013 \mathrm{j}$ & $0.315 \pm 0.007 \mathrm{i}$ \\
\hline & \multirow[t]{2}{*}{ High-Cd } & $\mathrm{Se} 0$ & $3.500 \pm 0.060 \mathrm{~b}$ & $1.468 \pm 0.094 \mathrm{a}$ & $0.126 \pm 0.001 d$ & $2.063 \pm 0.095 \mathrm{c}$ & $0.705 \pm 0.025 f$ & $2.023 \pm 0.024 \mathrm{a}$ & $1.443 \pm 0.074 \mathrm{a}$ \\
\hline & & Se1 & $3.679 \pm 0.031 \mathrm{a}$ & $1.407 \pm 0.124 \mathrm{ab}$ & $0.249 \pm 0.003 \mathrm{a}$ & $2.789 \pm 0.022 \mathrm{a}$ & $1.386 \pm 0.008 b$ & $1.465 \pm 0.034 \mathrm{~d}$ & $1.062 \pm 0.029 \mathrm{c}$ \\
\hline \multirow[t]{4}{*}{ V2 } & \multirow[t]{2}{*}{ Low-Cd } & $\mathrm{Se} 0$ & $1.562 \pm 0.110 \mathrm{e}$ & $0.756 \pm 0.031 \mathrm{~d}$ & $0.126 \pm 0.001 \mathrm{~d}$ & $0.061 \pm 0.044 \mathrm{~g}$ & $0.397 \pm 0.022 \mathrm{i}$ & $0.930 \pm 0.015 \mathrm{~g}$ & $0.885 \pm 0.031 \mathrm{e}$ \\
\hline & & Se1 & $1.215 \pm 0.061 \mathrm{~g}$ & $0.622 \pm 0.059 \mathrm{e}$ & $0.095 \pm 0.005 f$ & $1.005 \pm 0.021 \mathrm{f}$ & $0.526 \pm 0.023 \mathrm{~g}$ & $0.615 \pm 0.013 \mathrm{j}$ & $0.404 \pm 0.007 \mathrm{~h}$ \\
\hline & \multirow[t]{2}{*}{ High-Cd } & $\mathrm{Se} 0$ & $2.922 \pm 0.070 \mathrm{~d}$ & $1.136 \pm 0.048 \mathrm{c}$ & $0.110 \pm 0.001 \mathrm{e}$ & $1.615 \pm 0.041 \mathrm{e}$ & $0.916 \pm 0.024 \mathrm{~d}$ & $1.549 \pm 0.030 \mathrm{c}$ & $1.304 \pm 0.034 b$ \\
\hline & & Se1 & $3.259 \pm 0.123 c$ & $1.181 \pm 0.063 \mathrm{c}$ & $0.073 \pm 0.002 \mathrm{~g}$ & $2.456 \pm 0.092 b$ & $1.196 \pm 0.047 \mathrm{c}$ & $0.917 \pm 0.021 \mathrm{~h}$ & $0.698 \pm 0.029 f$ \\
\hline \multirow[t]{4}{*}{ V3 } & \multirow[t]{2}{*}{ Low-Cd } & $\mathrm{Se} 0$ & $1.373 \pm 0.136 f$ & $0.644 \pm 0.013 \mathrm{e}$ & $0.232 \pm 0.010 \mathrm{~b}$ & $0.495 \pm 0.018 \mathrm{~h}$ & $0.316 \pm 0.007 \mathrm{j}$ & $0.999 \pm 0.021 \mathrm{f}$ & $0.879 \pm 0.024 \mathrm{e}$ \\
\hline & & Se1 & $1.243 \pm 0.015 \mathrm{fg}$ & $0.521 \pm 0.011 \mathrm{e}$ & $0.139 \pm 0.002 \mathrm{c}$ & $0.949 \pm 0.024 f$ & $0.522 \pm 0.021 \mathrm{~h}$ & $0.791 \pm 0.030 \mathrm{i}$ & $0.516 \pm 0.024 \mathrm{~g}$ \\
\hline & \multirow[t]{2}{*}{ High-Cd } & $\mathrm{Se} 0$ & $3.136 \pm 0.078 \mathrm{c}$ & $1.198 \pm 0.019 \mathrm{c}$ & $0.131 \pm 0.002 \mathrm{~cd}$ & $1.778 \pm 0.080 \mathrm{~d}$ & $0.835 \pm 0.025 \mathrm{e}$ & $1.832 \pm 0.067 \mathrm{~b}$ & $1.463 \pm 0.083 \mathrm{a}$ \\
\hline & & Se1 & $3.390 \pm 0.044 b$ & $1.331 \pm 0.124 \mathrm{~b}$ & $0.113 \pm 0.004 \mathrm{e}$ & $2.729 \pm 0.131 \mathrm{a}$ & $1.605 \pm 0.038 \mathrm{a}$ & $1.308 \pm 0.049 \mathrm{e}$ & $0.972 \pm 0.058 \mathrm{~d}$ \\
\hline Cultivars & & & $* *$ & $*$ & $* *$ & $*$ & $* *$ & $* *$ & $* *$ \\
\hline $\mathrm{Cd}$ treatment & & & $* *$ & $* *$ & $* *$ & $* *$ & $* *$ & $* *$ & $* *$ \\
\hline Se treatment & & & $\mathrm{ns}$ & ns & $* *$ & $* *$ & $* *$ & $* *$ & $* *$ \\
\hline
\end{tabular}

Values shown are the mean $\pm \mathrm{SE}(n=3) .{ }^{\text {a }} \mathrm{V} 1, \mathrm{~V} 2$, and V3 represent rice variety "Huanghuazhan," rice variety "Cliangyou 386," and rice variety "Yuzhenxiang," respectively. ${ }^{b} \mathrm{Se} 0$, no Se application; Se1, Se application; $n s$, no significant effects; *significant effect at the $P<0.05$ level; **significant effect at the $P<0.01$ level. The same letter among are not significantly different according to Duncan's $(0.05)$

increase of the SOD, POD, CAT, and APX activities as well as protein and GSH contents and the decline of MDA and proline contents), indicating that the application effect of Se was affected by soil cadmium content.

\subsection{Relationship Between Rice Indicators}

Generally, the Cd content in the stems and leaves at the mature stage was highly related to the SOD, POD, CAT, and APX activities as well as the GSH content, whereas it 
Fig. 1 Effects of soil Cd contamination and foliar Se treatment on the MDA, protein, proline, and GSH contents in leaves of three rice cultivars at the flowering stage during 2017-2019. Values shown are the mean $\pm \mathrm{SE}(n=3) . \mathrm{V} 1$, $\mathrm{V} 2$, and $\mathrm{V} 3$ represent rice variety "Huanghuazhan," rice variety "Cliangyou 386," and rice variety "Yuzhenxiang," respectively. T1, T2, T3, and $\mathrm{T} 4$ represent the low-Cd area with no Se application, low-Cd area with Se application, high-Cd area with no Se application, and high-Cd area with Se application, respectively. $n s$, no significant effects; *significant effect at the $P<0.05$ level; **significant effect at the $P<0.01$ level. The same letter among are not significantly different according to Duncan's (0.05). MDA, malondialdehyde; $G S H$, glutathione

Fig. 2 Effects of soil Cd contamination and foliar Se treatment on the SOD, POD, CAT, and APX activities in leaves of three rice cultivars at the flowering stage during 2017-2019. Values shown are the mean $\pm \mathrm{SE}(n=3) . \mathrm{V} 1$, $\mathrm{V} 2$, and $\mathrm{V} 3$ represent rice variety "Huanghuazhan," rice variety "Cliangyou 386," and rice variety "Yuzhenxiang," respectively. $\mathrm{T} 1, \mathrm{~T} 2, \mathrm{~T} 3$, and $\mathrm{T} 4$ represent the low-Cd area with no Se application, low-Cd area with Se application, high-Cd area with no Se application, and high-Cd area with Se application, respectively. $n s$, no significant effects; *significant effect at the $P<0.05$ level; **significant effect at the $P<0.01$ level. The same letter among are not significantly different according to Duncan's (0.05). APX, ascorbate peroxidase; $C A T$ , catalase; $P O D$, peroxidise; $S O D$, superoxide dismutase
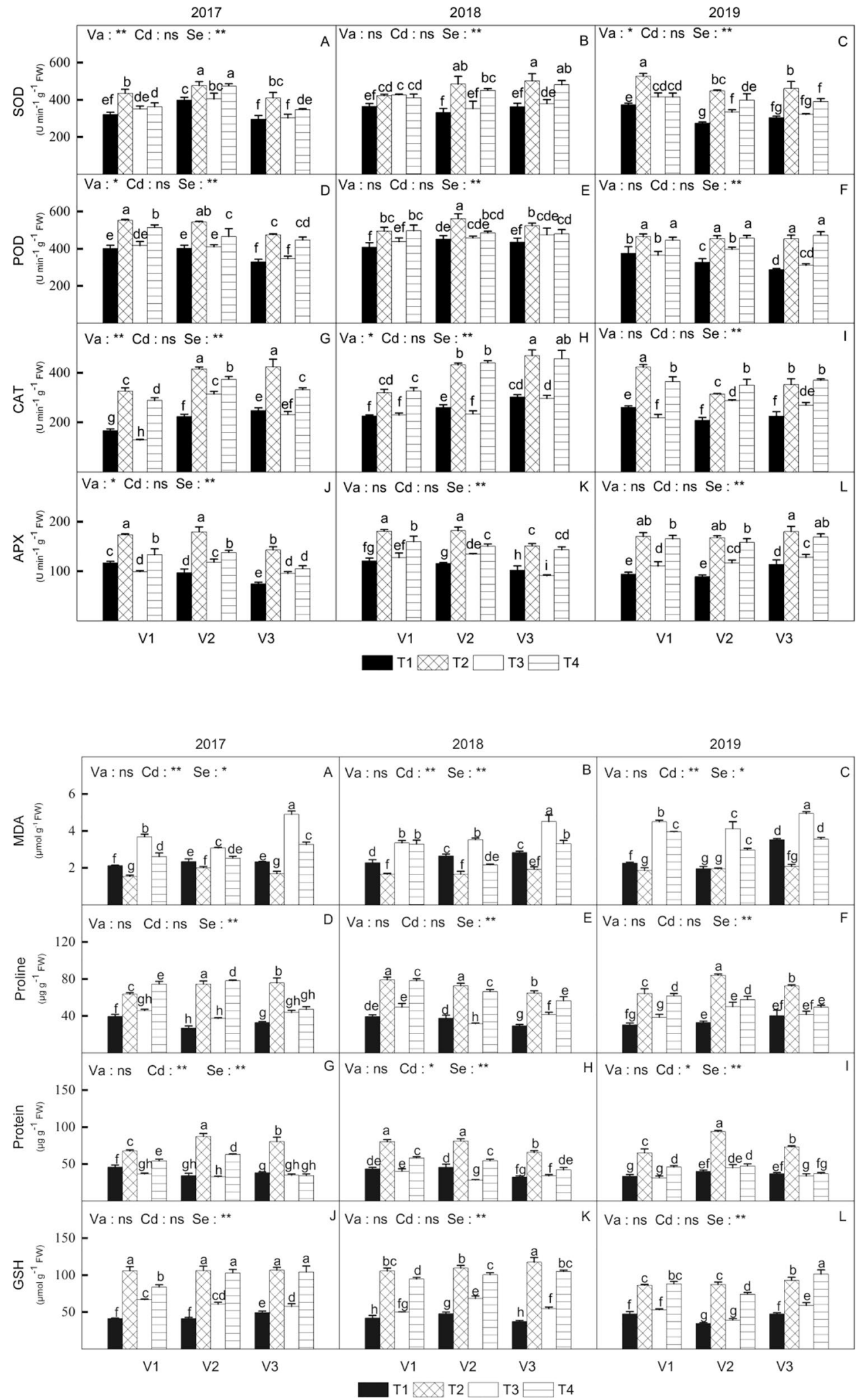

was negatively related to the proline content (Table 3 and Fig. 3). Moreover, the $\mathrm{Cd}$ content in the brown rice and spikes at the mature stage was highly related to the proline content but negatively related to the SOD, POD, CAT, and APX activities as well as protein and GSH contents. Furthermore, at the flowering stage, the protein content 
Fig. 3 Correlations of the $\mathrm{Cd}$ contents of rice, grain yield, yield components, and physiological indices. Sp-Ma, St-Ma, Le-Ma: Cd contents in spikes, stems, and leaves at the mature stage, respectively; $\mathrm{Sp}-\mathrm{Fl}$, St-Fl, Le-Fl: Cd contents in spikes, stems, and leaves at the flowering stage, respectively; $\mathrm{Cd}-\mathrm{Br}, \mathrm{Cd}$ content in brown rice; $1000-G W, 1000$ grain weight; $P D$, panicle density; $S F$, spikelet filling; $S g p$, protein; $S P P$, spikelets per panicle; Pro, proline; $A P X$, ascorbate peroxidase; $M D A$, malondialdehyde; $C A T$, catalase; $S O D$, superoxide dismutase; $P O D$, peroxidase

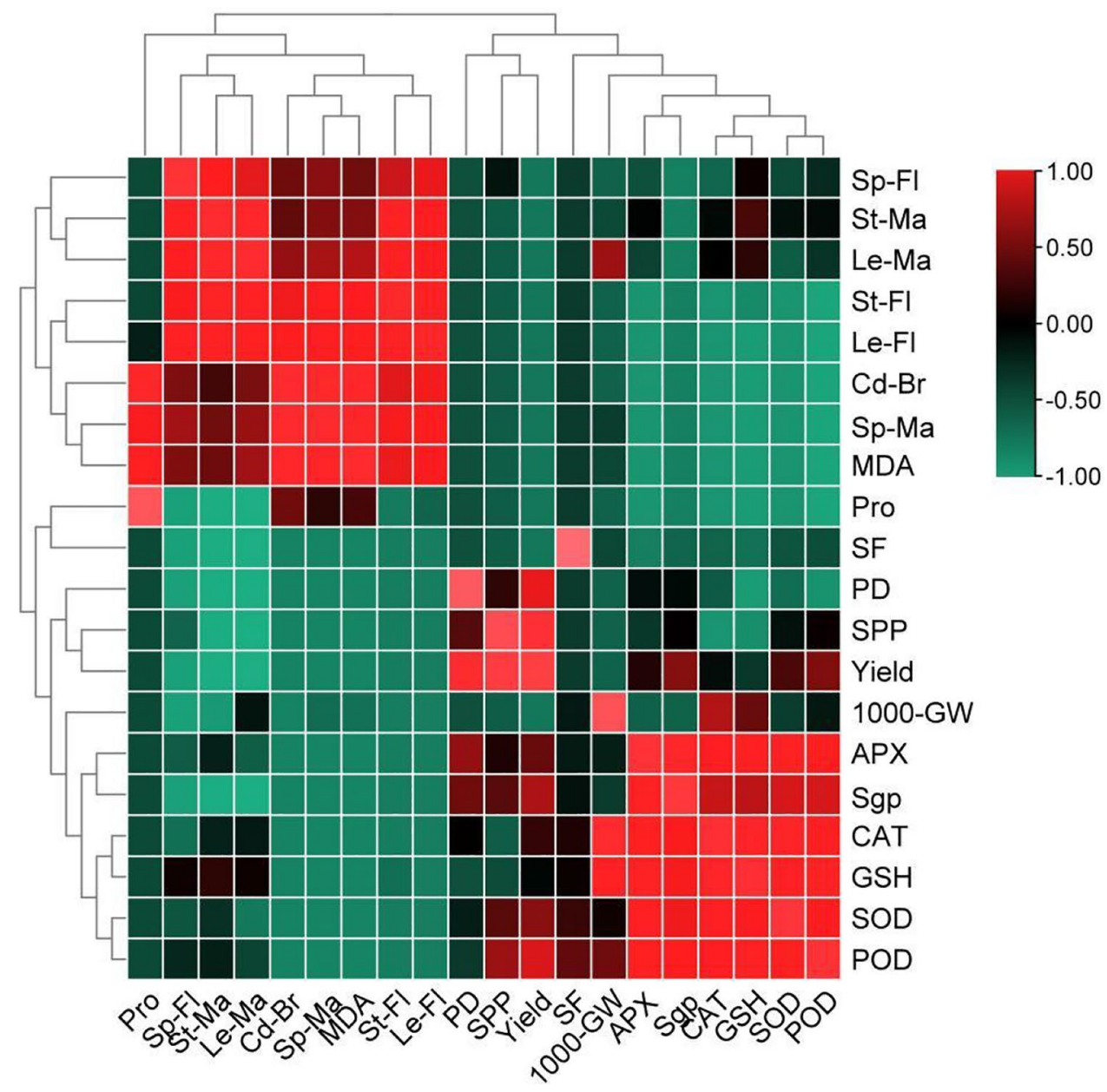

correlated negatively with the Cd content in the stems and leaves, whereas the proline content was negatively related to the $\mathrm{Cd}$ content in the spikes.

\subsection{Yield and Yield Composition}

There were significant differences in the panicle density, spikelets per panicle and the yield between different years (Fig. 4). The panicle density was the highest in 2019, and the spikelets per panicle and the yield in 2018 were significantly higher than that in 2019. CLY386 had the highest panicle density and yield. YZX had the highest 1000-grain weight. The spikelets per panicle of HHZ and CLY386 were significantly higher than that of YZX, and the spikelet filling of HHZ and YZX was significantly higher than that of CLY386. From low-Cd to high-Cd soils, panicle density, spikelets per panicle and yield averagely decreased by $2.73 \%, 3.65 \%$, and $6.82 \%$ from 2017 to 2019, respectively. Se application averagely increased 1000 -grain weight and grain yield by $4.02 \%$ and $7.58 \%$ from 2017 to 2019 , respectively.

\section{Discussion}

\subsection{Effects of Cadmium in Soil and Selenium Treatment on the Cadmium Content in Rice}

The difference in $\mathrm{Cd}$ content between different years may be related to the weather. The translocation of $\mathrm{Cd}$ from roots to the aboveground part is related to transpiration (Liu et al. 2016). Higher temperatures in 2019 (daily average temperature is $23.39{ }^{\circ} \mathrm{C}$ in $2017,21.66{ }^{\circ} \mathrm{C}$ in 2018 , and $22.37{ }^{\circ} \mathrm{C}$ in 2019) promoted transpiration and made the highest accumulation of $\mathrm{Cd}$ in rice (Table 2, 3, 4). CLY had the lowest $\mathrm{Cd}$ accumulation in the spikes at the mature stage, showing that CLY386 has more potential to produce low-Cd rice than the other two varieties. Increasing soil $\mathrm{Cd}$ content promoted the accumulation of $\mathrm{Cd}$ in rice, which was consistent with previous conclusions (Huang et al. 2017a, b). In the present study, Se application reduced the transport of $\mathrm{Cd}$ from stem and leaf to spike and brown rice (Table 2, 3,4). This result was different from that obtained by Gao et al. (2018), who reported that foliar Se application decreased the $\mathrm{Cd}$ content in the stems and spikes. 
Fig. 4 Effect of $\mathrm{Cd}$ and $\mathrm{Se}$ treatment on yield and yield components of 3 rice cultivars in 2017-2019. Values shown are the mean $\pm \operatorname{SD}(n=3)$. $\mathrm{V} 1, \mathrm{~V} 2$, and $\mathrm{V} 3$ represent rice variety "Huanghuazhan," rice variety "Cliangyou 386," and rice variety "Yuzhenxiang," respectively. $\mathrm{T} 1, \mathrm{~T} 2, \mathrm{~T} 3$, and $\mathrm{T} 4$ represent the low-Cd area with no Se application, low-Cd area with Se application, high-Cd area with no Se application, and high-Cd area with Se application, respectively. $n s$, no significant effects; *significant effect at the $P<0.05$ level; **significant effect at the $P<0.01$ level. The same letter among are not significantly different according to Duncan's (0.05)

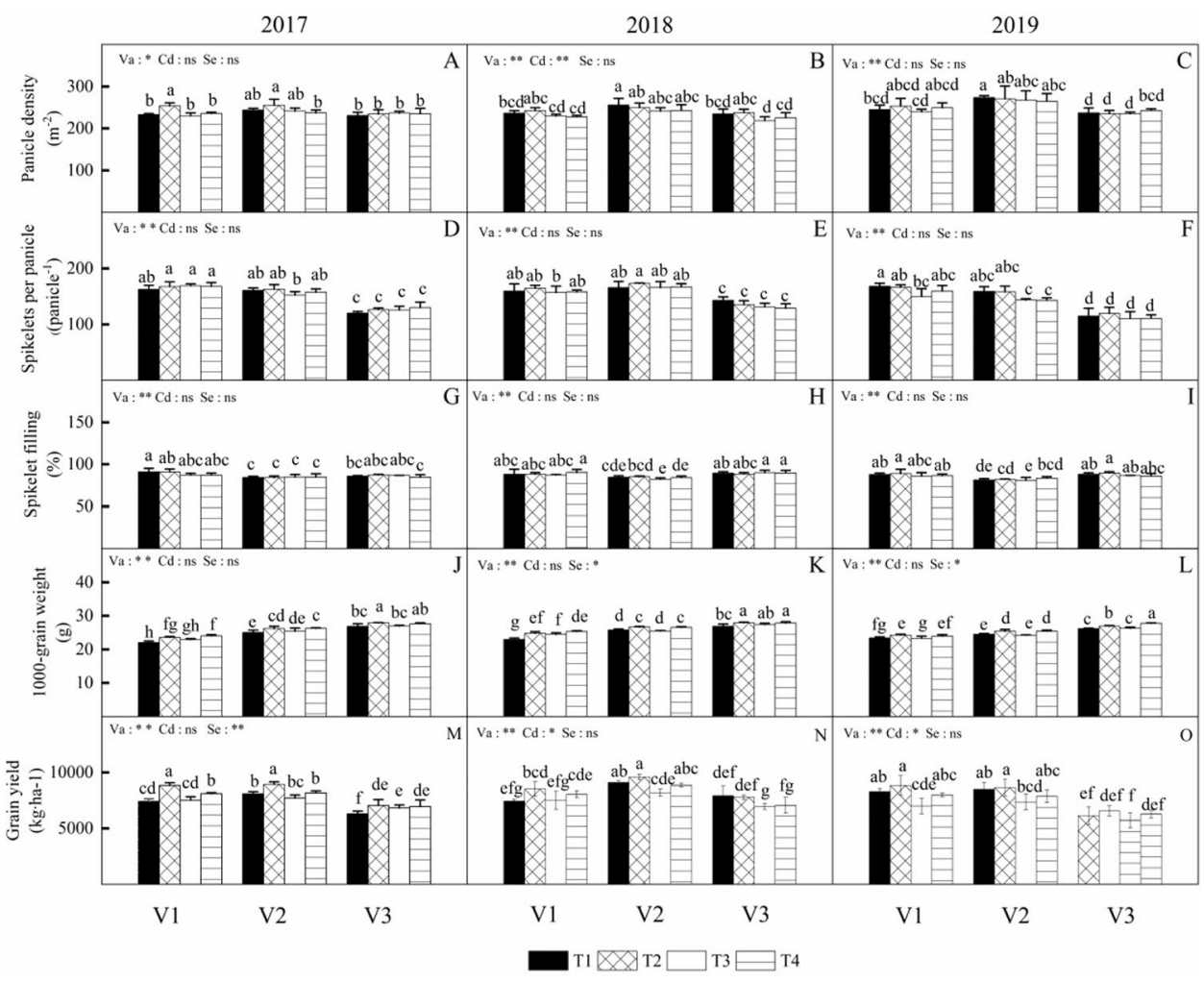

However, Gao et al. (2018) had conducted their study in a pot environment, in which there was no Se loss through leakage and runoff. Therefore, there was sufficient $\mathrm{Se}$ remaining in the soil to reduce $\mathrm{Cd}$ transport from the soil to the roots and thereby from the roots to the stem (Huang et al. 2017a, b). However, in our field experiment, leakage and runoff of the applied Se did occur, and thus what little $\mathrm{Se}$ amount that remained had failed to reduce $\mathrm{Cd}$ absorption by the roots. The finding that $\mathrm{Cd}$ accumulation had increased in the stems and leaves but decreased in the spikes and brown rice following foliar Se application confirmed that this mineral may reduce $\mathrm{Cd}$ transfer from the stems and leaves to the spikes at the filling stage, which was consistent with previous conclusions (Guo et al. 2021; Huang et al. 2021; Wang et al. 2020). The increase in GSH content by Se may be the reason why Se reduced the transport of Cd from stems and leaves to spikes (Fig. 1). The combination of GSH and Cd reduces the mobility of $\mathrm{Cd}$ in rice (Wan et al. 2016). In addition, Se reduced MDA content, increased antioxidant enzyme activity and soluble protein content (Fig. 2), which could maintain cell integrity and function, and enhance the plant's own mechanism of reducing Cd transport (Lin et al. 2012). Furthermore, Se application reduced $\mathrm{Cd}$ accumulation in brown rice by $47.49 \%$ in low-Cd soils and by $36.37 \%$ in high-Cd soils, indicating that although it has the capacity to reduce the transport of the heavy metal from the stems and leaves to the spikes, its effects are lowered when the soil Cd content is increased.

\subsection{Effects of Cadmium in Soil and Selenium Treatment on Rice Physiology}

In plant cells, SOD, POD, CAT, and APX are important antioxidant enzymes and GSH is an important nonenzymatic antioxidant substance which removes excessive free radicals (Wan et al. 2018). The protein content is an important indicator for measuring the total metabolism of plants (Liu et al. 2017). The synthesis, accumulation, and metabolism of proline, an osmotic small-molecule substance in plants, are regulated by abiotic stress and the intracellular proline concentration (Khan et al. 2015). The correlation analysis results (Table 3 and Fig. 3) showed that an increase in the accumulation of $\mathrm{Cd}$ in the stems and leaves stimulated both antioxidant enzyme synthesis and the GSH content and decreased the protein content, whereas an increase in the transportation of $\mathrm{Cd}$ from the stems and leaves to the spikes limited antioxidant enzyme synthesis and the GSH content, increased the proline content, and reduced metabolism in the rice plant. Additionally, the MDA content was highly related to the $\mathrm{Cd}$ content in rice, suggesting that MDA is an important indicator of membrane lipid peroxidation.

HHZ had the highest MDA content, indicating that HHZ's antioxidant capacity was weaker than that of the 
Table 5 Correlation between the $\mathrm{Cd}$ content in brown rice and various physiological indexes of leaves of three rice cultivars at the flowering stage during 2017-2019

\begin{tabular}{llllll}
\hline & SOD & POD & CAT & APX & GSH \\
\hline Cd content & $-0.530^{* *}$ & $-0.470^{* *}$ & $-0.500^{* *}$ & $-0.541^{* *}$ & $-0.414^{* *}$ \\
& MDA & $\mathrm{H}_{2} \mathrm{O}_{2}$ & $\mathrm{O} 2-$ & NR & NIR \\
Cd content & $0.905^{* *}$ & 0.064 & 0.011 & 0.073 & -0.049 \\
& PAL & Proline & Protein & Soluble sugar & MT \\
Cd content & 0.017 & $0.443^{* *}$ & $-0.449^{* *}$ & -0.036 & 0.146 \\
\hline
\end{tabular}

$n=36,{ }^{* *}$ significant correlation at the $P<0.01$ level. $S O D$, superoxide dismutase; $P O D$, peroxidise; $C A T$ , catalase; $A P X$, ascorbate peroxidase; $G S H$, glutathione; $M D A$, malondialdehyde; $N R$, nitrate reductase; $N I R$, nitrite reductase; $P A L$, phenylalanineammonialyase; $M T$, metallothionein other two varieties (Fig. 1). From low-Cd soils to high-Cd soils, MDA content increased and protein content reduced in the plant, which was consistent with the results of a previous study (Kanu et al. 2019; Wan et al. 2019). In plants, $\mathrm{Cd}$ induces lipid peroxidation, destabilises the balance of cellular oxidation, and increases the MDA content (Khan et al. 2015). In addition, Cd causes plants to produce reactive oxygen species and proteins to decompose, the protein content decreases as the Cd stress is intensified (Kanu et al. 2019). There was a difference between POD and APX activities in the 3 years which may be related to the different weather during the sampling period. CLY386 and YZX had higher CAT activities, which were related to the genetic characteristics of the variety itself. In this study, Se application enhanced the activities of SOD, POD, CAT, and APX (Fig. 2), which is consistent with the results of a previous study (Wan et al. 2019). The reason may be Se upregulate the enzymatic components of the antioxidant defence system and enhance the direct quenching of ROS (Hasanuzzaman et al. 2020). Se can reduce plant cell membrane damage by improving the photosynthetic apparatus, enhancing the direct quenching of ROS, and upregulating the enzymatic and nonenzymatic components of the antioxidant defence system. The Se-mediated reduction in MDA and proline contents maybe because this essential mineral promotes the synthesis of antioxidant enzymes to maintain oxidation balance and cell membrane lipid stability in rice (Huang et al. 2018). The increase in protein content caused by Se application is consistent with the results of a previous study (Reis et al. 2018). Se replaces sulphur in the sulphydryls in plants, promoting the production of sulphur-containing amino acids, such as selenomethionine and selenocystine, which are involved in protein synthesis (Schiavon and Elizabeth 2017). Additionally, Se is an essential component of RNA and participates in amino acid transport and protein synthesis (Reis et al. 2018). Se application increased the GSH content, which is consistent with the findings by other researchers (Wan et al. 2019). $\mathrm{Se}$, which has a similar chemical structure to that of sulphur, is an important component of GSH and can promote its production through the sulphur metabolism pathway in plants (Schiavon and Elizabeth 2017). However, because the role of $\mathrm{Se}$ is to reduce $\mathrm{Cd}$-induced lipid peroxidation and oxidative stress by increasing the antioxidant enzyme activity and protein content, its capacity to produce GSH declines with increasing $\mathrm{Cd}$ content in soils.

\subsection{Effects of Cadmium in Soil and Selenium Treatment on Rice Yield}

The higher production in 2018 was mainly due to the higher accumulated temperature in the rice-growing season in 2018 (Table 4). Compared with the other two varieties, CLY386 had greater yield potential. The increase in soil $\mathrm{Cd}$ content reduced the panicle density and yield, which is consistent with the results of a previous study (Rehman et al. 2015). Rice yield formation is mainly determined by the nutrients absorbed by the root system and the carbohydrates converted by photosynthesis (Tian et al. 2017). Reportedly, Cd can reduce the activities of nitrate reductase and nitrite reductase in the roots and leaves and decrease the assimilation of nitrates (Singh et al. 2018). Furthermore, Cd affects photosynthesis (damaging the light-harvesting complexes II, a photosynthetic system) and reduces the chlorophyll and carotenoid contents (Rizwan et al. 2018). Additionally, Cd affects the morphology of rice roots by reducing the amounts of coarse and medium roots and increasing the proportion of fine roots as well as reducing nutrient absorption (Huang et al. 2017a, b). The results obtained in this study support our conclusion that $\mathrm{Cd}$ limits the establishment of the nutrient structure and rice yield formation through photosynthesis during the filling period. Se application increased the 1000-grain weight and yield, which is consistent with the results of a previous study (Huang et al. 2017a, b). Se has been reported to increase the photosynthetic rate and carbohydrate accumulation in plants (Gao et al. 2018), supporting our conclusion that its application improves leaf function during the filling stage and increases the 1000 -grain weight and yield (Table 5). 


\subsection{Application of Selenium in Cadmium-contaminated Fields}

In our study, foliar application of Se reduced the translocation of $\mathrm{Cd}$ from stems and leaves to spikes. It was reported that the interaction of $\mathrm{Se}$ and $\mathrm{Cd}$ on rice was closely related to the concentration of Se and Cd (Ding et al. 2014). In this study, foliar application of Se under low-Cd soil has a better effect on reducing the $\mathrm{Cd}$ content in brown rice. If the soil $\mathrm{Cd}$ content in $\mathrm{Cd}$-contaminated areas is divided, the $\mathrm{Cd}$ content in grains reduced by foliar Se spraying in low-Cd areas would be more cost-effective than soil improvement and water/fertilizer management, while it may provide better ecological protection and improve rice yield and quality (Honma et al. 2016; Rehman et al. 2015). Moreover, the operation of foliar Se spraying is easier and quicker than traditional breeding and is more accepted by the public than molecular breeding (Huang et al. 2017a, b). Our study showed that Se also has the potential to increase rice yield.

\section{Conclusions}

In this study, Se reduced the oxidative stress caused by $\mathrm{Cd}$ and increases rice yield. Se reduced Cd transportation from the stems and leaves to the spikes, thus reducing the content of the heavy metal in brown rice, especially in low-Cd soils. Unfortunately, foliar application of Se failed to reduce the $\mathrm{Cd}$ content in brown rice of the three rice varieties to less than the safety limit $\left(0.2 \mathrm{mg} \mathrm{kg}^{-1}\right)$. So, it is necessary from now on to use more rice varieties or improve Se application methods to produce low-cadmium rice.

Acknowledgements This study was supported by the National Key Research and Development Plan (2017YFD0301403-06).

Author Contribution Shuochen Jiang: methodology, software, formal analysis, investigation, writing — original draft, writing — review and editing, and visualization. Bin Du: methodology, investigation, and writing - review and editing. Qixia Wu: data curation and writingreview and editing. Haiwei Zhang: software, data curation, and writing — review and editing. Youyu Deng: investigation and data curation. Xiangru Tang: conceptualization, methodology, project administration, resources, formal analysis, investigation, writing — original draft, writing - review and editing, and supervision. Jianqiang Zhu: conceptualization, methodology, project administration, resources, formal analysis, investigation, writing — original draft, writing—review and editing, funding acquisition, and supervision.

Data Availability The data used to support the findings of this study are available from the corresponding author upon request.

Open Access This article is licensed under a Creative Commons Attribution 4.0 International License, which permits use, sharing, adaptation, distribution and reproduction in any medium or format, as long as you give appropriate credit to the original author(s) and the source, provide a link to the Creative Commons licence, and indicate if changes were made. The images or other third party material in this article are included in the article's Creative Commons licence, unless indicated otherwise in a credit line to the material. If material is not included in the article's Creative Commons licence and your intended use is not permitted by statutory regulation or exceeds the permitted use, you will need to obtain permission directly from the copyright holder. To view a copy of this licence, visit http://creativecommons.org/licenses/by/4.0/.

\section{References}

Deng X, Liu K, Li M, Zhang W, Zhao X, Zhao Z, Liu X (2017) Difference of Selenium Uptake and Distribution in the Plant and Selenium Form in the Grains of Rice with Foliar Spray of Selenite or Selenate at Different Stages. Field Crop Res 211:165-171. https:// doi.org/10.1016/j.fcr.2017.06.008

Ding Y, Feng R, Wang R, Guo J, Zheng X (2014) A dual effect of Se on Cd toxicity: evidence from plant growth, root morphology and responses of the antioxidative systems of paddy rice. Plant Soil 375:289-301. https://doi.org/10.1007/s11104-013-1966-8

Du B et al (2019) Rice seed priming with sodium selenate: effects on germination seedling growth, and biochemical attributes. Sci RepUk 9:4311. https://doi.org/10.1038/s41598-019-40849-3

Gao M, Zhou J, Liu H, Zhang W, Hu Y, Liang J, Zhou J (2018) Foliar spraying with silicon and selenium reduces cadmium uptake and mitigates cadmium toxicity in rice. Sci Total Environ 631632:1100-1108. https://doi.org/10.1016/j.scitotenv.2018.03.047

GB 5009.15-2014 National Food Safety Standard Determination of Cadmium in Food GB 5009.15-2014 National Food Safety Standard Determination of Cadmium in Food

Guo Y et al (2021) Exogenous selenium (cadmium) inhibits the absorption and transportation of cadmium (selenium) in rice. Environmental pollution 268:115829. https://doi.org/10.1016/j.envpol. 2020.115829

Hasanuzzaman M et al (2020) Selenium in plants: boon or bane? Environ Exp Bot 178:104170. https://doi.org/10.1016/j.envexpbot. 2020.104170

Honma T, Ohba H, Kaneko-Kadokura A, Makino T, Nakamura K, Katou H (2016) Optimal soil $\mathrm{Eh} \mathrm{pH}$ and water management for simultaneously minimizing arsenic and cadmium concentrations in rice grains Environ. Sci Technol 50:4178-4185. https://doi.org/ 10.1021/acs.est.5b05424

Huang B, Xin J, Dai H, Zhou W (2017) Effects of interaction between cadmium $(\mathrm{Cd})$ and selenium $(\mathrm{Se})$ on grain yield and $\mathrm{Cd}$ and $\mathrm{Se}$ accumulation in a hybrid rice (Oryza sativa L) System. J Agr Food Chem 65:9537-9546. https://doi.org/10.1021/acs.jafc.7b03316

Huang G, Ding C, Guo F, Li X, Zhang T, Wang X (2017) Underlying mechanisms and effects of hydrated lime and selenium application on cadmium uptake by rice (Oryza sativa L) seedlings. Environ Sci Pollut Res Int 24:18926-18935. https://doi.org/10.1007/ s11356-017-9573-5

Huang G, Ding C, Guo F, Zhang T, Wang X (2018) The optimum Se application time for reducing Cd uptake by rice (Oryza sativa $\mathrm{L}$ ) and its mechanism. Plant Soil 431:231-243. https://doi.org/10. 1007/s11104-018-3768-5

Huang $\mathrm{H}$ et al (2021) Synergistic effect of silicon and selenium on the alleviation of cadmium toxicity in rice plants. J Hazard Mater 401:123393. https://doi.org/10.1016/j.jhazmat.2020.123393

Huang S et al (2020) Application of Inorganic Passivators Reduced Cd Contents in Brown Rice in Oilseed Rape-Rice Rotation under Cd Contaminated Soil. Chemosphere (oxford) 259:127404. https:// doi.org/10.1016/j.chemosphere.2020.127404

Kanu AS, Ashraf U, Mo Z, Sabir SU, Baggie I, Charley CS, Tang X (2019) Calcium amendment improved the performance of fragrant rice and reduced metal uptake under cadmium toxicity. Environ 
Sci Pollut Res Int 26:24748-24757. https://doi.org/10.1007/ s11356-019-05779-7

Keskinen R, Räty M, Yli-Halla M (2011) Selenium Fractions in Selenate-Fertilized Field Soils of Finland. Nutr Cycl Agroecosys 91:17-29. https://doi.org/10.1007/s10705-011-9435-3

Khan MIR, Nazir F, Asgher M, Per TS, Khan NA (2015) Selenium and sulfur influence ethylene formation and alleviate cadmiuminduced oxidative stress by improving proline and glutathione production in wheat. J Plant Physiol 173:9-18. https://doi.org/ 10.1016/j.jplph.2014.09.011

Li H, Luo N, Li YW, Cai QY, Li HY, Mo CH, Wong MH (2017) Cadmium in rice: transport mechanisms influencing factors and minimizing measures. Environ Pollut 224:622-630. https://doi. org/10.1016/j.envpol.2017.01.087

Li S, Zhang G, Gao W, Zhao X, Deng C, Lu L (2015) Plant growth, development and change in GSH level in safflower (Carthamus tinctorius L) exposed to copper and lead. Arch Biol Sci 67:385396. https://doi.org/10.2298/ABS140910006L

Lin L, Zhou W, Dai H, Cao F, Zhang G, Wu F (2012) Selenium reduces cadmium uptake and mitigates cadmium toxicity in rice. J Hazard Mater 235-236:343-351. https://doi.org/10.1016/j.jhazmat.2012. 08.012

Liu H, Wang H, Ma Y, Wang H, Shi Y (2016) Role of transpiration and metabolism in translocation and accumulation of cadmium in tobacco plants (Nicotiana tabacum L). Chemosphere 144:1960 1965. https://doi.org/10.1016/j.chemosphere.2015.10.093

Liu X, Zhao Z, Duan B, Hu C, Zhao X, Guo Z (2015) Effect of applied sulphur on the uptake by wheat of selenium applied as selenite. Plant Soil 386:35-45. https://doi.org/10.1007/s11104-014-2229-Z

Liu Y, Zhang C, Zhao Y, Sun S, Liu Z (2017) Effects of Growing Seasons and Genotypes on the Accumulation of Cadmium and Mineral Nutrients in Rice Grown in Cadmium Contaminated Soil. The Science of the Total Environment 579:1282-1288. https://doi. org/10.1016/j.scitotenv.2016.11.115

Qingqing H, Yiyun L, Xu Q, Lijie Z, Xuefeng L, Yingming X (2019) Selenite Mitigates Cadmium-Induced Oxidative Stress and Affects Cd Uptake in Rice Seedlings under Different Water Management Systems. Ecotox Environ Safe 168:486-494. https://doi.org/10. 1016/j.ecoenv.2018.10.078

Rehman MZ et al (2015) Effect of inorganic amendments for in situ stabilization of cadmium in contaminated soils and its phyto-availability to wheat and rice under rotation. Environ Sci Pollut Res Int 22:16897-16906. https://doi.org/10.1007/s11356-015-4883-y

Reis HPG et al (2018) Agronomic biofortification of upland rice with selenium and nitrogen and its relation to grain quality. J Cereal Sci 79:508-515. https://doi.org/10.1016/j.jcs.2018.01.004

Rizwan M et al (2018) Residual effects of biochar on growth, photosynthesis and cadmium uptake in rice (Oryza sativa L.) under Cd stress with different water conditions. J Environ Manage 206:676683. https://doi.org/10.1016/j.jenvman.2017.10.035

Schiavon M, Elizabeth AHP (2017) The fascinating facets of plant selenium accumulation - biochemistry, physiology, evolution and ecology. The New phytologist 213:1582-1596. https://doi.org/10. 1111/nph.14378

Sharma I, Kaur N, Pati PK (2017) Brassinosteroids: a promising option in deciphering remedial strategies for abiotic stress tolerance in rice. Front Plant Sci 8:2151. https://doi.org/10.3389/fpls.2017. 02151

Singh P, Singh I, Shah K (2018) Reduced activity of nitrate reductase under heavy metal cadmium stress in rice: an in silico answer Front. Plant Sci 9:1948. https://doi.org/10.3389/fpls.2018.01948

Tian G et al (2017) Improving Rice Population Productivity by Reducing Nitrogen Rate and Increasing Plant Density. Plos One 12:e182310. https://doi.org/10.1371/journal.pone.0182310

Treesubsuntorn C, Dhurakit P, Khaksar G, Thiravetyan P (2018) Effect of microorganisms on reducing cadmium uptake and toxicity in rice (Oryza sativa L.). Environ Sci Pollut Res Int 25:2569025701. https://doi.org/10.1007/s11356-017-9058-6

Uraguchi S, Mori S, Kuramata M, Kawasaki A, Arao T, Ishikawa S (2009) Root-to-shoot Cd translocation via the xylem is the major process determining shoot and grain cadmium accumulation in rice. J Exp Bot 60:2677-2688. https://doi.org/10.1093/jxb/erp119

Wan Y, Camara AY, Yu Y, Wang Q, Guo T, Zhu L, Li H (2018) Cadmium dynamics in soil pore water and uptake by rice: influences of soil-applied selenite with different water managements. Environ Pollut 240:523-533. https://doi.org/10.1016/j.envpol.2018.04.044

Wan Y, Wang K, Liu Z, Yu Y, Wang Q, Li H (2019) Effect of selenium on the subcellular distribution of cadmium and oxidative stress induced by cadmium in rice (Oryza sativa L). Environ Sci Pollut R 26:16220-16228. https://doi.org/10.1007/s11356-019-04975-9

Wan Y, Yu Y, Wang Q, Qiao Y, Li H (2016) Cadmium Uptake Dynamics and Translocation in Rice Seedling: Influence of Different Forms of Selenium. Ecotox Environ Safe 133:127-134. https:// doi.org/10.1016/j.ecoenv.2016.07.001

Wang C et al (2020) Effects and mechanisms of foliar application of silicon and selenium composite sols on diminishing cadmium and lead translocation and affiliated physiological and biochemical responses in hybrid rice (Oryza sativa $\mathrm{L}$ ) exposed to cadmium and lead. Chemosphere (Oxford) 251:126347. https://doi.org/10. 1016/j.chemosphere.2020.126347

Zhang M, Tang S, Huang X, Zhang F, Pang Y, Huang Q, Yi Q (2014) Selenium uptake, dynamic changes in selenium content and its influence on photosynthesis and chlorophyll fluorescence in rice (Oryza sativa L.) Environ Exp Bot:39-45

Zhang X, Chen D, Zhong T, Zhang X, Cheng M, Li X (2015) Assessment of cadmium (Cd) concentration in arable soil in China. Environmental science and pollution research international 22:49324941. https://doi.org/10.1007/s11356-014-3892-6

Publisher's Note Springer Nature remains neutral with regard to jurisdictional claims in published maps and institutional affiliations. 